811.163.41'366.58

https://doi.org/10.18485/kij.2021.68.2.2

ДУШКА Б. КЛИКОВАЦ*

Универзитет у Београду

Филолошки факултет
Оригинални научни рад

Примљен: 11.10.2021.

Прихваћен: 08.11.2021.

\title{
О ВРЕМЕНСКИМ (ИНДИКАТИВНИМ) ЗНАЧЕЊИМА ГЛАГОЛСКИХ ВРЕМЕНА У СРПСКОМ ЈЕЗИКУ (2)
}

\begin{abstract}
У раду се разматрају временска значења глаголских времена у српском језику на основу приступа који је установио А. Белић, а развили и модификовали други граматичари. Објашњава се појам временског (индикативног) значења, а затим и његове врсте - апсолутно, релативно и безвременско. Коментаришу се решења у важећој граматици за средњу школу која ауторка сматра спорним, са ослонцем на постојећу литературу. На крају се објашњени теоријски апарат примењује на анализу текста.
\end{abstract}

Кључне речи: српски језик, временска значења глаголских времена, апсолутна значења, релативна значења, презент, перфекат, аорист, имперфекат, плусквамперфекат, приповедање.

\section{7. Аорист}

Аорист је свакако један од глаголских облика чије дефиниције изазивају највише недоумица. ${ }^{1}$ Ж. Станојчић каже да „индикативно” употребљен аорист „означава радњу која се извршила у моменту говорења, саопштавања о њој, или се вршила до једног тренутка у томе времену" (122010: 395), напомињући да се тада могу употребити прилози сада (кад је глагол свршеног вида) одн. досад (кад је глагол несвршен). Ево једног примера који наводи:

(1) Сад је баш сретох на степеницама.

У вези с овим најпре ћемо приметити да је сама дефиниција нејасна: радња „која се извршила у моменту говорења, саопштавања о њој” морала би бити

*klikovac@fil.bg.ac.rs

${ }^{1}$ Ово је други део рада чији је први део објављен у истом овом часопису, бр. 1, год. LXVIII, 2021, стр. 33-46. 
радња која је у тренутку говора већ извршена; јер да није, била би напоредна с ТГ и морала би бити означена презентом. А ако је у тренутку говора већ извршена, онда таква дефиниција обухвата свако претеритално време, а не само аорист. Затим, дефиниција и пример се не слажу, јер у примеру аорист означава радњу која се одиграла непосредно пре ТГ.

Релативни аорист пак „означава да су се радња, стање или збивање вршили, односно извршили у једном одређеном времену у прошлости, које је изван времена када се о њима саопштава" (Станојчић $\left.{ }^{12} 2010: 396\right)$. А на другом месту аутор каже да и индикативни и релативни аорист „означавају, пре свега, доживљене радње" (исто: 396, истицање изворно). Шта је, онда, дистинктивно за аорист: време у којем се ситуација одиграла, одређеност времена у прошлости или доживљеност?

Сладојевић (1955) наводи низ примера, из различитих извора, у којима апсолутни аорист означава радње које се нису десиле у непосредној прошлости - чак могу бити веома удаљене од ТГ. Ево једног од његових примера, где је аорист ,употребљен за радњу од прије три мјесеца”:

(2) Људи смо па грешимо. Од праоца нашег грех нам је остао. И ми се огрешисмо о тебе. Али нам је Господ дао савест, па кад увидимо грех свој, ми се покајемо... Огрешисмо душу о тебе, сине мој, о тебе, ни крива ни дужна, и о ове неопојане гробове! (Ј. Веселиновић)

Сладојевић закључује да се аорист „употребљава за прошлост уопште, без обзира на то колико је она удаљена од тренутка говора говорног лица" (1955: 135), а његово значење дефинише овако: „,А]орист [...] значи прошлу, ограничену по трајању радњу коју је говорно лице лично запазило или на неки начин доживјело" (исто: 135-136). ${ }^{2}$

Исто мишљење има и Вуковић (1967: 104), који сматра следећи пример убедљивим доказом да аорист не означава само непосредну прошлост:

(3) Слуго моја, Тодоре везире, виђе ли ми Роксанду ђевојку?

- Вићех, царе, и прстеновах је,

а разлику између (крњег) перфекта и аориста илуструје примером у којем перфекат означава прошлу радњу која је резултативна за садашњост, а аорист доживљену прошлу радњу (исто: 384$)$ :

\footnotetext{
Пр о суло се жито по поду, - видим само да је жито просуто - и: Пр о су се жито по поду, - видео сам жито кад се просипало.
}

${ }^{2}$ Аутор каже и следеће: „Она компонента у аористу коју су наши синтаксичари схватили као значење блискости радње уствари је значење доживљености радње. Иначе тачно је да се у синтаксичком индикативу аорист највише употребљава за радње које припадају непосредној или блиској прошлости. То долази отуд што је осјећање доживљености најјаче за блиске радње, јер су оне најсвјежије у сјећању" (1955: 135, истицање изворно). 
Такође истиче да аорист „увек са собом носи и стилистичко (експресивно) обележје" (исто: 356).

Иако има дијалеката у којима је аорист и даље жив у свакодневној употреби (како је било и у Сладојевићевом и Вуковићевом говору), С. Савић и В. Половина (Савић/Половина 1989) налазе да је у њиховом корпусу разговорног београдског језика аорист „веома редак” (забележен је само 25 пута - насупрот, рецимо, више од 1700 примера за перфекат). Такође бележе да је то најчешће глагол рећи у 1. л. јд., као у примеру: Ја реко (изузетно рекох) они су откачени (исто: 19, 22). Приметићемо да је тај глагол у аористу (и то само у 1. л. јд., и то обично без $x$ ) постао нека врста речце којом говорник сигнализира да је оно што следи његова помисао - често претпоставка или предвиђење - коју је имао у прошлој ситуацији о којој приповеда; сам аорист би, дакле, у том случају био употребљен приповедачки.

По нашем језичком осећању (које такође потиче из београдске средине), аорист исказује прошле догађаје експресивно - и то је једина његова разлика у односу на перфекат. Аористом говорник може исказати различите субјективне ставове: чуђење (пр. 4, 5), изненађеност догађајем (пр. 6), оцену догађаја као непријатног или непожељног (пр. 7); може њиме упутити прекор саговорнику (пр. 8), или просто унети дозу неформалности, фамилијарности у разговор (пр. 9). Ситуације означене аористом у пр. 4, 6, уопште не морају припадати блиској прошлости, а ситуација означена пр. 9 јој засигурно не припада:

(4) Био је баш лоше [=болестан]. И извуче се!

(5) Чу ли ти шта он оно рече!

(6) Ју, испаде ми из руке!

(7) Колико сам ходала, отпадоше ми ноге!

(8) [Говорник саговорнику који се управо вратио кући:] Што ми не рече да ћеш излазити, могао си да купиш хлеб!

(9) [Професор у поруци колегама:] Ја пређох на онлајн прошле недеље.

Аорист може бити употребљен и приповедачки, о чему ће бити речи у т. 10 .

\section{8. Имперфекат}

И у вези с овим глаголским обликом постоје у литератури различита објашњења. Станојчић наводи да имперфекат означава „радњу, стање или збивање који су се вршили у одређено време у прошлости", и то напоредо с неком другом прошлом ситуацијом, која може бити означена неким прошлим временом или временском прилошком одредбом - због чега му је значење увек релативно. Такође, „[о]бележен је значењем доживљености” ('22010: 397, курзив изворни).

С друге стране, Сладојевић и Вуковић такође сматрају да имперфекат означава доживљену прошлу радњу, али истичу њену неограниченост. Сладојевић (1953: 218) каже да се „имперфектом не износи радња као временска цјелина, 
него као трајање коме у нашој свијести нијесу присутне границе”, а Вуковић (1967: 380-381) да се имперфектом обележава прошла радња „коју доживљавамо у њену току". ${ }^{3}$ Оба аутора наводе примере у којима имперфекат означава радње и у ближој и у даљој прошлости. Сладојевић (1953: 219) истиче да радња означена имперфектом не мора бити напоредна с неком другом прошлом радњом одн. временском ситуацијом. На другом месту (1966: 55-57) закључује да се имперфекат најчешће употребљава у апсолутном значењу, будући да обично значи прошлост у односу на ТГ; исто налази и К. Милошевић (1977).

Навешћемо неколико примера које даје Сладојевић (1966) - за апсолутно значење у описима прошлих трајних ситуација $(п р .1,2)$ и за његово релативно значење (пр. 3). Танасић (2005), који такође дефинише имперфекат као „претеритални глаголски облик који исказује у њихову трајању” (2005: 430), налази да имперфекат може означавати и понављане прошле радње (исто: 431) - било итеративне (пр. 4), било оне које представљају избројиву вишекратност; рекли бисмо да се у том случају - аналогно презенту (в. т. 4.2 овог рада) - такође може сматрати апсолутним, будући да је период понављања прошли у односу на ТГ.

(1) Ено бијаше велика гужва пред Народним позориштем. (Сладојевић 1953: 216)

(2) А дијете растијаше, и јачаше у духу и пуњаше се премудрости. (Сладојевић 1966: 43)

(3) Гордо лежи велики војвода / под кључевма крви благородне / ка̂ малопред што гордо ићаше... (Сладојевић 1966: 41, 57)

(4) Сањаше је, у мукама, скоро сваку ноћ. (Танасић 2005, М. Црњански)

Познато је да је имперфекат веома редак у говору, па и у књижевним делима. Стога је занимљиво приметити да у преводу романа Џ. Р. Р. Толкина Силмарилион (Београд: Стилос, 2012) неки делови просто врве од њега:

(5) Мелкор беше љубоморан на њега, јер Ауле беше најсличнији њему по уму и моћима [...]. Обојица такође жуђаху да стварају своја сопствена бића и појаве које ће бити нове и од других несмишљене, и уживаху у похвалама своје вештине. Али Ауле остаде веран Еруу и потчињаваше све што је чинио његовој вољи [...] (стр. 28).

Овакви примери показују да имперфекат није нестао из српског језика, него је отишао у резервни стилски фонд. Занимљиво је, међутим, што у наведеном роману он није употребљен првенствено да архаизује текст, него да означи ситуације које су се одиграле у дубокој прошлости (рецимо, у примеру 5 Толкин говори о времену убрзо после стварања света). Тако је имперфекат, захваљујући својој сопственој архаичности (тј. чињеници што се раније употребљавао чешће

${ }^{3}$ Имперфекат се по томе разликује од аориста несвршених глагола, који исказује прошлу доживљену радњу као целину (Вуковић 1967: 381), односно „ограничено трајање прошле радње” (Сладојевић 1953: 219, курзив изворни). 
него данас) почео да означава далеку прошлост ситуација које су њиме означене. Та веза између облика који припада прошлости и њиме означене ситуације, која се такође тумачи да припада (далекој) прошлости, јесте, дакако, метонимијска.

\section{9. Да ли глаголско време мења природу свог значења ако је употребљено с прилошком одредбом?}

О релативном перфекту Станојчић каже и да је то „обично онај чије се (из)вршење радњи може означити временским прилошким одредбама онда, maда, тога дана и сл., односно контекстом у којем се налази одређен другим прошлим временима” ( $\left.{ }^{12} 2010: 392\right)$. Исто тако, релативни аорист „означава да су се радња, стање или збивање вршили, односно извршили у једном одређеном времену у прошлости, које је изван времена када се о њима саопштава. На то одређено време може се указивати прилошким одредбама тада, онда, јуче, прошле године и сл.", а пример је следећи (исто: 396):

(1) Тада дође мој друг и договорисмо се да учимо. После неколико дана положили смо испит.

Видели смо (т. 8) да слично тврди и за имперфекат, који је „само релативно време". Да ли је, дакле, глаголско време употребљено релативно само зато што је с њим употребљена нека прилошка одредба или што се везује за неку другу прошлу ситуацију?

Сладојевић на основу анализе примера закључује да „временска везаност глаголске радње за одређену ситуаџију сама по себи не чини употребу глаголскога облика релативском”, односно да „употреба времена уз прилоге (и др. прилошке одредбе) за вријеме може бити индикативна у ужем смислу и она је врло често таква" (1966: 33, 35, истицање изворно). А Вуковић (1967: 402) такве случајеве овако коментарише:

\footnotetext{
Да ли ће се рећи: Ишао сам у шуму [...] или Јуче сам ишао у шуму, - то за наше питање припадности апсолутивном индикативу остаје потпуно ирелевантно: и у једном и у другом случају имамо прошлост диференцирану у односу према правој садашњости (апсолутив), са разликом само што је у другом случају радња у прошлости временски фиксирана (специфицирана), а у првом случају тога нема.
}

У складу са ова два последња мишљења, даћемо још један пример, у коме обе реченице - и она са презентом и она са перфектом - означавају исту прошлу ситуацију, при чему прилошка одредба кад сам ушла у собу прецизира о ком прошлом тренутку је реч:

(2а) Кад сам ушла у собу, а он спава.

(2б) Кад сам ушла у собу, он је спавао. 
Дакле, означена ситуащија је иста, али значење презента и перфекта није исто - из једноставног разлога што презент типично означава садашњост, а перфекат прошлост. У случају презента ситуација се представља са гледишта њене истовремености с прошлим тренутком, а у случају перфекта са гледишта претхођења тренутку говора. Стога само презент има релативно значење, а значење перфекта је апсолутно.

\section{0. Приповедачка употреба глаголских времена}

У т. 4.1. навели смо пример који Станојчић ('22010: 388) даје за наративни презент; ево га још једанпут:

(1) Пре неколико дана ㅆдемо нас двојица улицом, гледамо излоге и управо пред књижаром сретнемо Петра. Уђемо у књижару и купимо књигу коју нам је он одавно тражио.

Приповедачку употребу помиње и у вези с аористом (пр. 2) и имперфектом (један од примера је и 3 ) - иако не и у вези са перфектом:

(2) Седамдесетак година после Карађорђеве буне, зарати се опет у Србији и одмах граница одговори устанком. Опет плануше и турске и српске куће на висовима... Први пут после толико година освануше на капији одсечене главе погубљених Срба... Али све то не потраја дуго. Чим рат између Турске и Србије престаде, свет се умири. Истина, то је био привидан мир. (И. Андрић)

(3) У њиховим узвицима, Вук Исакович се чињаше као неки хришћански светитељ.

Међутим, очигледно је да у овим примерима имамо две врсте ситуација. О томе говори Сладојевић, који разликује „динамичку компоненту приповиједања, коју сачињава низ радња које сљедују једна за другом и казују промјене стања ствари”, и „статичку компоненту, коју сачињавају радње којима се описује неко стање ствари или неки предмет, лице итд.” (1966: 39). Динамичка компонента се састоји од изношења основног приповедачког низа, који је „скуп радња које (свака за себе) представљају прелаз из једнога стања ствари у друго, другим ријечима радња које мијењају стање ствари”. То је „срж приповиједања”, „приповиједање (или причање) у најужем смислу” (исто: 18). У пр. 2 подвучени глаголи износе управо радње које припадају основном приповедачком низу, које померају причу по корак даље, а у пр. 3 чињаше се означава статичку ситуацију - ону која је једнолично трајала неко време у прошлости; у пр. 2 аутор приповеда, у пр. 3 описује. 
Сладојевић наводи и најважније глаголске облике који означавају радње из основног приповедачког низа; то су: аорист (свршених глагола), перфекат (свршених глагола), презент свршених глагола и презент несвршених глагола. ${ }^{4}$ Илустроваћемо их једним једноставним примером:

\begin{tabular}{|c|c|c|c|}
\hline $\begin{array}{c}\text { Приповедачки } \\
\text { перфекат }\end{array}$ & $\begin{array}{c}\text { Приповедачки } \\
\text { аорист }\end{array}$ & $\begin{array}{c}\text { Приповедачки } \\
\text { презент од } \\
\text { свршених глагола }\end{array}$ & $\begin{array}{c}\text { Приповедачки } \\
\text { презент од } \\
\text { несвршених } \\
\text { глагола }\end{array}$ \\
\hline $\begin{array}{l}\text { Мачка је мја- } \\
\text { укнула, птица } \\
\text { се препала и } \\
\text { одлетела. }\end{array}$ & $\begin{array}{l}\text { Мачка мјаукну, } \\
\text { птица се препа- } \\
\text { де и одлете. }\end{array}$ & $\begin{array}{l}\text { Мачка мјаукне, } \\
\text { птица се препадне } \\
\text { и одлети. }\end{array}$ & $\begin{array}{l}\text { Мачка мјауче, } \\
\text { птица се пре- } \\
\text { пада и одлеће. }\end{array}$ \\
\hline
\end{tabular}

Иако су догађаји који сачињавају основни приповедачки низ исти, између ових кратких приповедачких текстова постоји осетна стилска разлика, која потиче од употребљених глаголских облика. Приповедање у перфекту је најмирније, фактографско, објективно, као да долази од неангажованог посматрача; у аористу и презенту свршених глагола је живахно и сликовитије; презент несвршених глагола чини да се догађаји одвијају пред нашим очима као у успореном филму.

Слично примећују и други аутори. Поредећи примере Јуче сам био у шуми и срео сам вука и Јуче идем кроза шуму, па сретнем вука, у којима је, како видимо, употребљен по један приповедачки перфекат (срео сам) и приповедачки презент (сретнем), Вуковић (1967: 364) каже да употреба перфекта изразу даје „чисто информативни карактер”, а презентом се догађај чини „предочљивијим”. А Станојчић констатује да „[о]блици аориста уносе у приповедање динамичност [...]. Његовом употребом писац приближава читаоцу радњу - као доживљену, па отуда упечатљивију" (стр. 396). ${ }^{5}$

Што се тиче типа значења ових глаголских времена, Сладојевић (1966: 3941) истиче да приповедачки перфекат и приповедачки аорист износе догађаје који су се одиграли у прошлости, која је прошлост „према тренутку приповједачевога говора”, тако да имају „,апсолутновременско значење”. ${ }^{6}$ Презент сврше-

${ }^{4}$ Као што је познато, приповедачки могу бити употребљени и футур I (нпр. На то ће peћu најстарији син у смислу „на то рече”) и императив (Повуци, потегни, ишчупаше репу, у смислу „повукоше, потегоше").

${ }^{5}$ Можда би била на месту напомена да је свако приповедање, будући да се састоји од низања догађаја који мењају стање ствари и причу померају даље, по својој природи динамично. Аорист само уноси додатну динамичност у односу на перфекат.

${ }^{6}$ Стевановић ( $\left.{ }^{3} 1979\right)$ не помиње приповедачки перфекат, али за перфекат у примерима као што је Мића је застао, извадио марамицу и обрисао Ненадово лице, затим га узео за руку и повео га кући (Б. Ћосић) каже да је употребљен апсолутно. 
них глагола има безвременско значење (в. т. 3.4 овог рада). Што се тиче презента несвршених глагола, њиме се обично „казују стварно перфективне радње”, те је и таква употреба презента безвременска (Сладојевић 1966: 21). Таква вредност несвршеног презента добро се види ако покушамо да радње њиме означене пребацимо у прошлост; на пример, текст из горње табеле неће гласити Мачка је мјаукала, птица се препадала и одлетала, него ћемо несвршене глаголи заменити свршенима.

Важно је истаћи да се радње из основног приповедачког низа не оријентишу једна према другој, него само иду једна за другом (по Стевановићу (ํ1979: 615), оне „граматички падају у једно исто време”), а цео низ се оријентише према ТГ.

Сам приповедачки текст, како смо видели, по правилу се не састоји само од изношења следа догађаја, него се тај поступак комбинује с описивањем, „статичком компонентом приповедања”. Ти описи ситуација, понављане или трајне ситуације у прошлости исказују се несвршеним глаголима у презенту, перфекту (пуном или крњем) или, евентуално, имперфекту. Први од три облика има тада релативно значење, а преостала два апсолутно.

Таква комбинација се одлично види на почетку приповедачких текстова: они обично почињу описом некаквог једноличног стања ствари које је трајало неко време у прошлости - у питању су трајна стања или понављане радње. Они се обично исказују перфектом (типичан је крњи перфекат глагола бити). На том фону онда почиње заплет - приповедање (у смислу изношења основног приповедачког низа радњи). Тако у пр. 4 крњи перфекат била на самом почетку приповетке, а затим и пуни перфекат није имала, означавају трајна стања у прошлости, а перфекат молила се ситуацију која се у прошлости понављала. После описа тог почетног стања ствари започиње са̂мо приповедање, које се најављује и лексички - одредбом једно вече; следе догађаји, који мењају стање ствари и исказани су глаголима у свршеном презенту (у тексту су подвучени двоструком линијом): ${ }^{7}$

(4) Била једна царица која није имала од срца порода, па се једнако молила богу да јој да̂ да роди. Једно вече, молећи се тако, уздахне и рече:

- Та дај ми, боже, од срца порода, да би и љута змија била!

После некога времена она се осети трудна, и кад буде на том доба, оㅡㄴ змију, па је стане неговати, хранити, дојити, као свака мати своје дете.

Такође, основни приповедачки низ може се прекинути описом статичке ситуације. Тако у пр. 5 тече приповедање у аористу (глаголи су подвучени двоструком равном линијом), затим писац прелази на приповедачки перфекат (подвучен је таласастом линијом), а онда на опис статичке ситуације помоћу перфекта несвршених глагола (глаголи су подвучени једноструком линијом):

(5) Наслонише се на њега, а затим клонуше, загрљени, прво девојка а он по њој, у рачвасто крушково дебло, као у спремну постељу. Без гласа

${ }^{7}$ Изузетак је глагол рећи, који се најчешће јавља у аористу чак и онда кад само приповедање тече у приповедачком презенту свршених глагола. 
и покрета, она још није пружала отпор, али кад младићеве руке клиз-

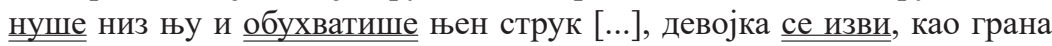
коју у берби савијају и која се отима. Није ни есетио како га је дигла са себе ни како се нашао опет на стази. До његових ногу клечала је девојка, склопљених руку и лица уздигнута ка њему, потпуно као у молитви. [...] Клечећи, склопљених руку, она је изговарала речи које он није познавао, али које су му у том тренутку биле јасније од његових матерњих [...]. (И. Андрић)

Можемо приметити да Андрић на приповедачки перфекат, који износи прошле догађаје фактографски, прелази у тренутку младићевог отрежњења, док је живост аориста одговарала његовом претходном узбуђењу и уроњености у доживљај. У рукама умешног стилисте глаголска времена су моћно оруђе.

\section{1. Закључак}

Верујемо да је већ и из овог нашег разматрања очигледно да у литератури о значењима глаголских облика постоји више решења за исти проблем - често управо супротних. Треба додати и да практично не постоје два аутора која у свему нуде истоветна решења. Стога се на основу литературе може склопити и сасвим другачија слика значења глаголских времена него она коју смо ми овде приказали. Ипак сматрамо да је ова наша, иако ни издалека није потпуна, у основи кохерентна и интуитивно прихватљива - толико да омогућава и подучавање употребама глаголских времена у школи и њихово учење.

Ево резимеа питања о којима смо у раду говорили.

- $\mathrm{У}$ својим временским (индикативним) значењима глаголска времена смештају ситуацију коју означавају у неки временски одсечак - прошлост, садашњост или будућност. Ситуација означена глаголским временом може се оријентисати према ТГ; тада се каже да то глаголско време има апсолутно значење. Ако се ситуација означена глаголским временом оријентише према неком другом (прошлом или будућем) тренутку, кажемо да то глаголско време има релативно значење. Свршени глаголи у презенту имају тзв. безвременско значење - кад је означена ситуација смештена на временску линију, али са̂мо то место распознаје се тек у контексту (т. 3 овог рада).

- $\quad$ Релативно значење се од апсолутног разликује само по оријентационој тачки, а све друго остаје исто. То значи да у релативном презенту, исто као и у апсолутном, могу стајати само несвршени глаголи (т. 4.1).

- К Кад су у питању понављане ситуације, период њиховог понављања такође има оријентациону тачку, тј. такође припада прошлости, садашњости или будућности (т. 4.2.).

- $\quad$ Презент несвршених глагола који означава будуће ситуације је у исто време и релативни - јер означава ситуације истовремене с будућим тре- 
нутком, али и модални - јер се говорник „преселио” у будући тренутак под дејством јаке намере или уверености да ће се ситуација остварити. Исто важи и за значења будућности која могу имати перфекат и аорист: говорник се, чврсто уверен да ће се нешто десити, „преселио” у будући тренутак и из њега ситуације посматра као већ остварене (т. 4.3).

- $\quad$ Презент с везником да уопште не смешта ситуацију на временску линију, него само именује радњу (као и инфинитив, с којим алтернира), па његово значење можемо назвати ванвременским (т. 4.4).

- Перфекат може имати резултативно значење - кад означава радњу која је не само претходила ТГ него је и оставила последице које важе у ТГ (апсолутни резултативни перфекат), односно радњу која је претходила некој другој радњи и оставила последице које су важиле у времену те друге радње (релативни резултативни перфекат) (т. 5).

- Плусквамперфекат означава прошлу радњу која је претходила некој другој прошлој радњи; притом је обично, мада не и неопходно, резултативна за њу. Овај глаголски облик може означавати и прошлу радњу која је нерезултативна за садашњост (т. 6).

- $\quad$ Аорист означава доживљену прошлу радњу, без обзира на то кад се она одиграла у прошлости. У савременом језику његово значење често се своди на експресивно означавање прошле ситуације (т. 7).

- Имперфекат означава доживљену прошлу ситуацију у њеном трајању (без обзира на то кад се догодила у прошлости), а у књижевности се може употребити и да означи ситуације из далеке прошлости (т. 8).

- Временско одређивање прошле ситуације прилошком одредбом не утиче на тип значења глаголског времена: оно не добија релативно значење пуком чињеницом што је ситуација временски одређена (т. 9).

- Приповедачки употребљена глаголска времена означавају догађаје који мењају стање ствари, који померају причу даље, који су окосница приповедања. Најчешћа таква глаголска времена јесу перфекат (само од свршених глагола), аорист (такође само од свршених глагола) и презент (од свршених и, ређе, од несвршених глагола). Перфекат и аорист имају апсолутно значење, а свршени и несвршени презент безвременско. Приповедање се комбинује са описом трајних или понављаних ситуација, за које се најчешће употребљавају презент (релативни) или перфекат (апсолутни) несвршених глагола (т. 10).

Пре него што, у додатку овом раду, погледамо како би изгледала примена назначеног теоријског апарата на конкретан текст, даћемо још једну напомену. Иако je, да би се утврдило значење неког глаголског времена, неопходно установити према ком тренутку се оријентише ситуација означена тим временом (било да је она једнократна или понављана), сама та оријентација често није довољна да би се значење глаголског времена прецизно утврдило. Већ смо видели, на пример, да релативни презент може имати значења и прошлости и будућности (т. 3.2), а 
да безвременски презент може имати значења и прошлости и садашњости и будућности (т. 3.4). Исто тако, и апсолутни презент може имати више значења: може означавати актуелну садашњост (пр. 1), радње као особине (пр. 2), ситуације које се понављају у садашњости (пр. 3), као и тзв. свевременске ситуације (пр. 4):

(1) Не чујем те ништа, Марија пева у другој соби.

(2) Марија лепо пева. [= има способност да лепо пева]

(3) Сваки пут кад пере судове, Марија пева.

(4) Земља се окреће око Сунца.

Слично томе, различита значења (у тесној вези са глаголским видом) има и апсолутни перфекат: у пр. 5 означава прошлу радњу која је оставила последице у садашњости (резултативно значење), у пр. 6 је употребљен приповедачки, а у пр. 7 и 8 означава трајне, односно понављане ситуације у прошлости:

(5) Купила сам новине, ево ти.

(6) Прошетала сам, купила новине и вратила се кући.

(7) Читала сам новине цело поподне.

(8) Читала сам новине сваки пут кад би их неко донео.

Такође, аорист је употребљен апсолутно и кад експресивно означава прошлу ситуацију и кад означава догађаје из приповедачког низа.

\section{2. Глаголска времена у тексту: пример анализе}

Сада када располажемо овим теоријским алаткама за анализу значења глаголских времена, можемо погледати како изгледа анализа везаног текста. У ту сврху послужиће нам одломак из романа Сеобе М. Црњанског.

Једном заста $\underline{(1)}_{\text {у том љуљању и хујање му у глави преста }}$, тако да осети $\underline{(3)}_{(2)}$ да је ${ }_{(4)}$ будан. Лежао је ${ }_{(5)}$ у мраку широм отворених очију, зачуђен, и дрхтећи од хладноће. Није више

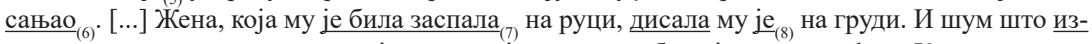
$\underline{\text { aзва }}_{(9)}$, протегливши врат, $\underline{y y}_{(10)}$, јер толика још тишина била је ${ }_{(11)}$ пред кућом. Кроз пукотину

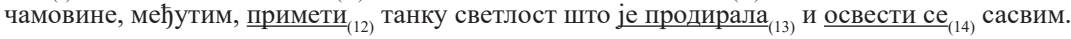

(М. Црњански, Сеобе)

У овом тексту износи се развој једне прошле ситуације, а очигледно је да аутор у њему у њему и приповеда и описује. Анализу ћемо започети управо проналазећи ,динамичку компоненту приповедања” - односно радње које сачињавају основни приповедачки низ, оне од којих свака чини корак даље у развоју приче. То су радње означене глаголима заста (1), преста (2), осети (3), изазва (9), чу (10), примети (12), освести се (14). Приповедање, дакле, тече у аористу. ${ }^{8}$

${ }^{8}$ Облици аориста и презента су понекад истоветни. У горњем тексту то важи за облике осети, примети, освести се. Међутим, ако је облик бар неких (или чак и једног јединог) глагола недвосмислено облик презента или аориста, разумно је претпоставити - нарочито кад је аутор и иначе пажљив 
Сви други глаголски облици везују се, непосредно или посредно, за ту основну приповедачку нит. Презент је (4) означава трајну прошлу ситуацију која обухвата тренутак означен аористом осети (синтаксички, употребљен је у изричној зависној реченици која допуњава тај глагол); стога је употребљен релативно. Облици перфекта лежао је (5), није сањао (6) и дисала је (8), саграђени од несвршених глагола, означавају стања у прошлости која су трајала неко време, и то после радње означене аористом осети; пошто су та стања прошла у односу на ТГ (тј. у односу на време у којем аутор приповеда), тај перфекат има апсолутно значење. Исто значење има и перфекат била је (11), који означава сразмерно трајну ситуацију која обухвата радњу означену аористом чу, и продирала је (13), чија ситуација обухвата тренутак примети. (Треба нагласити да је ситуација означена несвршеним перфектом продирала је каснија од ситуација лежао је, није сањао, дисала је, била је тишина; међутим, то не значи да је тај перфекат приповедачки, јер ти глаголи у перфекту не означавају ситуације које мењају стање ствари.)

Плусквамперфекат је била заспала (7) означава радњу која је претходила радњи дисала је, али је и резултативна за њу: жена му је дисала баш на груди зато што му је претходно заспала на руци.

Најзад, у тексту су употребљена и два глаголска прилога: садашњи (дpx-

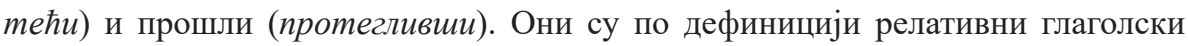
облици, јер означавају ситуације истовремене, односно антериорне у односу на ситуације означене реченичним предикатом (лежао је, односно чу).

\section{ЛИТЕРАТУРА}

Белић 1998 [21958]: Александар Белић, О језичкој природи и језичком развитку - Лингвистичка испитивања, Кюига I, [у књизи] Александар Белић, Општа лингвистика (прир. М. Ивић), Београд: Завод за уџбенике и наставна средства, 1998, стр. 13-392.

Вуковић 1967: Jovan Vuković, Sintaksa glagola - Studije, Sarajevo: Zavod za izdavanje udžbenika, 1967.

Живковић 1963: Sreten Živković, „Glavna funkcija perfekta”, Ivšićev zbornik, Zagreb: Hrvatsko filološko društvo, 1963, str. 415-420.

Ивић 1980: Милка Ивић, „О значењу српскохрватског плусквамперфекта”, Зборник за филологију и лингвистику, XXIII/1, стр. 93-100.

Катичић 1981: Radoslav Katičić, „Kategorija gotovosti u vremenskom značenju glagolskih oblika”, Jezik, god. 29, br. 1, 1981, str. 3-13.

стилиста - да је цео приповедачки низ означен истим глаголским обликом, односно да аутор глаголске облике не мења насумично. 
Кликовац 2004: Duška Klikovac, „O važnosti pojmovnih metafora za proučavanje leksikona srpskohrvatskog jezika”, [u knjizi] Metafore u mišljenju i jeziku, Beograd: XX vek, 2004, str. 113-163.

Кликовац 2018: Душка Кликовац, „О презенту несвршених глагола за означавање будућих ситуација”, [у књизи] Српски језик у светлу когнитивне лингвистике, Београд: Друштво за српски језик и књижевност Србије, 2018, стр. 217-232.

Милошевић 1977: Ksenija Milošević, „O pitanju 'relativskog' karaktera srpskohrvatskog imperfekta", Zbornik radova povodom 70. godišnjice života akademika Jovana Vukovića, Sarajevo: ANUBiH, 1977, str. 247-260.

Радовановић 1990: Milorad Radovanović, „O pluskvamperfektu”, [u knjizi] Spisi iz sintakse i semantike, Sremski Karlovci: Izdavačka knjižarnica Zorana Stojanovića / Novi Sad: Dobra vest, 1990, str. 183-199.

РСАНУ: Речник српскохрватског књижевног и народног језика, I-XX, Београд: САНУ.

Савић/Половина 1989: Svenka Savić, Vesna Polovina, Razgovorni srpskohrvatski jezik, Novi Sad: Filozofski fakultet, 1989.

Сладојевић 1953: Петар Сладојевић, „О имперфекту у српскохрватском језику", Јужнословенски филолог, ХХ, 1953, стр. 213-228.

Сладојевић 1955: Петар Сладојевић, „О значењу аориста у српскохрватском језику", Јужнословенски филолог, ХХІ, 1955, стр. 131-136.

Сладојевић 1966: Петар Сладојевић, О основним временским категоријама употребе глаголских облика у српскохрватскоме језику, Београд: Научна књига, 1966.

Станојчић 122010: „Систем глаголских облика и његова употреба”, [у књизи] Живојин Станојчић, Љубомир Поповић, Граматика српског језика за гимназије и средюе школе, Београд: Завод за уџбенике, 2010. (12. издање), стр. 387-409.

Стевановић ${ }^{3}$ 1979: Михаило Стевановић, Савремени српскохрватски језик II - Синтакса, Београд: Научна књига, 1979. (3. издање).

Танасић 2005: Срето Танасић, „Синтакса глагола”, у: Пипер, Предраг и др., Синтакса савременога српског језика - Проста реченища, Београд: Институт за српски језик САНУ / Београдска књига / Матица српска, 2005, стр. 345-476.

Танасић 2020: Срето Танасић, „Кратак увод у синтаксу глагола српског језика", Наш језик, књ. LI, св. 1, 2020, стр. 1-42. 
Duška B. Klikovac

\section{ON THE TEMPORAL (INDICATIVE) MEANINGS OF VERB TENSES IN SERBIAN}

\section{Summary}

This paper discusses the temporal meanings of verb tenses in the Serbian language against the background of the approach established by A. Belić and its further elaborations and modifications by other grammarians. Firstly, the notion of temporal (indicative) meaning is elucidated, as well as its types - absolute, relative, and timeless. Then the current secondary school grammar book interpretations which the author finds problematic are discussed, in light of the pertinent literature. Finally, the presented theoretical apparatus is applied to text analysis.

Keywords: Serbian, temporal meanings of verb tenses, absolute meanings, relative meanings, present, perfect, aorist, imperfect, pluperfect, narration. 